Aristide Laurel Mokale Kognou ${ }^{1}$ Theodora Kopa Kowa ${ }^{2}$ / Pradeep Pateriya ${ }^{3}$ / Prem Narayan Pal ${ }^{3}$ / Raymond Simplice Mouokeu ${ }^{4}$ / Alembert Tchinda Tiabou ${ }^{2}$ / Gabriel Agbor Agbor ${ }^{2}$ /

Rajesh Pawar Singh ${ }^{3}$ / Rosalie Annie Ngono Ngane $^{5}$

\title{
Pharmacological evidence of Vitex thyrsiflora, Entandrophragma cylindricum, and Anonidium mannii used for the management of inflammation in Cameroon
}

\author{
${ }^{1}$ Centre for Research on Medicinal Plants and Traditional Medicine, Institute of Medical Research and Medicinal Plants Stud- \\ ies, Ministry of Scientific Research and Innovation, P.O. Box 13033, Yaoundé, Cameroon, Phone: +(237)674670414, E-mail: \\ nafaaris@yahoo.fr \\ ${ }^{2}$ Centre for Research on Medicinal Plants and Traditional Medicine, Institute of Medical Research and Medicinal Plants Stud- \\ ies, Ministry of Scientific Research and Innovation, P.O. Box 13033, Yaoundé, Cameroon \\ ${ }^{3}$ Laboratory of Pharmacognosy, Phytochemistry and Ethnopharmacology, Faculty of Pharmacy, VNS Croup of Institutions, \\ VNS Campus, Vidya Vihar, Neelbud-462044, Bhopal, India \\ ${ }^{4}$ Institute of Fisheries and Aquatic Sciences, University of Douala, P.O. Box 2701, Douala, Cameroon \\ ${ }^{5}$ Laboratory of Biochemistry, Faculty of Science, University of Douala, P.O. Box 24157, Douala, Cameroon
}

\begin{abstract}
:
Background: Inflammation is the most common health problem faced in life relating to a vast number of diseases. The present study evaluated the pharmacological effect of three plants (Vitex thyrsiflora, Entandrophragma cylindricum, and Anonidium mannii) commonly used in the Cameroon pharmacopeia for the management of inflammatory response.

Methods: The pharmacological effect was characterized by the antioxidant capacity, anti-inflammatory, analgesic, and antipyretic properties of the ethanol extracts of the three plants. Antioxidant capacity was determined using total phenolic content, total flavonoid content, hydrogen peroxide, ferric reducing antioxidant power (FRAP), 2,2-diphenyl-1-picrylhydrazyl (DPPH), and 2,2'-azinobis(3-ethylbenzothiazoline-6-sulfonate) (ABTS) radical scavenging assays. Anti-inflammatory activity was evaluated in vitro by protein denaturation and hypotonic-induced hemolysis methods and in vivo by carrageenan paw edema method. Analgesic and antipyretic activities were studied in vivo using acetic acid-induced writhing and brewer's yeast-induced hyperpyrexia models.

Results: All selected extracts showed high phenolic (15.93-64.45 mgCAE/g) and flavonoid (336.03-1053.48 mg$\mathrm{CAE} / \mathrm{g})$ contents and high ferric reducing power $(288.75-364.91 \mathrm{mgCAE} / \mathrm{g})$. These extracts exhibited good DPPH ( $\left.\mathrm{IC}_{50}=0.30-1.65 \mu \mathrm{g} / \mathrm{mL}\right)$, ABTS $\left(\mathrm{IC}_{50}=0.52-1.90 \mu \mathrm{g} / \mathrm{mL}\right)$, and $\mathrm{H}_{2} \mathrm{O}_{2}\left(\mathrm{IC}_{50}=1.40-3.55 \mu \mathrm{g} / \mathrm{mL}\right)$ radical scavenging activities. All extracts inhibited protein denaturation (6.79-82.27\%) and protected the erythrocyte membrane from lysis induced by hypotonic solution (18.90-88.00\%). The extracts significantly reduced dosedependent paw edema $(\mathrm{p}<0.05)$, fever, and abdominal writhing $(\mathrm{p}<0.001)$ especially at $400 \mathrm{mg} / \mathrm{kg}$.

Conclusions: All extracts exhibited interesting antioxidant properties, as well as significant anti-inflammatory, analgesic, and antipyretic effects.
\end{abstract}

Keywords: analgesic activity, anti-inflammatory activity, antipyretic activity, ethanol extract, medicinal plants, DOI: $10.1515 / \mathrm{jbcpp}-2019-0053$

Received: March 25, 2019; Accepted: December 13, 2019

\section{Introduction}

Scientists began taking interest in inflammatory disorders at the beginning of the 17th century, and since then, many studies were focused on the inflammatory reactions and etiology [1]. This is important because, in many diseases, a large part of tissue damage is due to the inflammatory responses, which, in itself, is responsible for 
the discomfort induced by the disease. Inflammation is a normal physiological defense response or an adaptation to aggression, which may be caused by a microorganism or any substance foreign to the organism [2]. It is one of the most important mechanisms of the body's defenses and requires fine regulation. Generally, in the case of a microorganism, inflammation leads to the elimination of the pathogen and the return to homeostasis of the injured tissue [3]. However, an inadequate response may lead to immunodeficiency that can degenerate to secondary infection or cancer [4]. Exacerbated on the contrary, inflammation increases morbidity and mortality in diseases such as rheumatoid arthritis, Crohn's disease, diabetes, cardiovascular diseases, Alzheimer's disease, and arteriosclerosis [5]. If poorly controlled, inflammation can spread to the rest of the body through the bloodstream [6]. It can then lead to irreversible local or generalized tissue damage, sometimes to septic shock leading, in the most severe cases, to death [6].

The inflammatory response involves different phases in which a large number of cells, particularly neutrophils, phagocytic cells, and macrophages, play a preponderant role in inflammatory mechanisms, as they are the first line of defense against infectious agents. Accumulation of these different cells at the inflammatory site will induce the release and increased accumulation of reactive oxygen species (ROS) [7]. If ROS production is too high and natural antioxidant systems are not efficient, cells are subjected to oxidative stress, which maintains the inflammatory state [8]. Therefore, ROS neutralization by antioxidants and radical scavengers could attenuate inflammation. In addition, inflammatory reaction leads to pain, heat, edema, and redness. Depending on the inflammatory severity, a fever characterized by an increase in temperature may appear [9].

The conventional treatment of inflammation is based on the provision of nonsteroidal (NSAIDs) and steroidal (SAIDs) anti-inflammatory drugs. Anti-inflammatory drugs affect the initiating or enhancing effects of inflammation (migration of inflammatory cells, release of prostaglandins and leukotrienes, ROS). However, the use of synthetic anti-inflammatory molecules essentially is not without harmful effects for the body. SAIDs have hormonal activity, mainly related to metabolic regulation, and exert a braking effect on the hypothalamicpituitary-adrenal axis [10]. All NSAIDs, regardless of their administration route, are at risk for gastrointestinal tract disorders, kidney and skin toxicity. The risk is even greater when dosage is high and treatment is prolonged [11]. Therefore, search for active molecules with low side effects is necessary. Such molecules are present in plants that are sometimes the only source of treatment for the local poor people. Indeed, there is evidence that natural products modulate various inflammatory mediators and have an effect on the expression of the pro-inflammatory molecules (cyclooxygenase 2, inducible nitric oxide synthase, interleukin $1 \beta$, tumor necrosis factor $\alpha$ and interleukin 10), which are the key to inflammation [12]. Many traditional medicines have a promising potential in the management of the pathologies currently afflicting humans, including inflammatory disorders. However, although increasingly used, many remain untested and used empirically. As a result, scientific knowledge of their efficacy and potential side effects is limited. This makes the identification of therapies and the promotion of their rational use more difficult.

This study aimed to show the therapeutic effects of the ethanol extracts of three medicinal plants, Vitex thyrsiflora (EtOHVT), Entandrophragma cylindricum (EtOHEC), and Anonidium mannii (EtOHAM) used in the management of inflammation.

\section{Materials and methods}

\section{Plant material}

The different plant parts used (leaves of $V$. thyrsiflora, stem barks of E. cylindricum and A. mannii) were collected from the Littoral and Centre Regions of Cameroon. Plants were identified at the National Herbarium (Yaoundé, Cameroon), where a voucher specimen was deposited. Detailed information on each medicinal plant is given in Table 1.

Table 1: General information and reports on evidence of biological activities and chemistry of the studied plants.

\begin{tabular}{|c|c|c|c|c|}
\hline $\begin{array}{l}\text { Species (family); } \\
\text { voucher numbera; } \\
\text { vernacular name }\end{array}$ & Traditional uses & 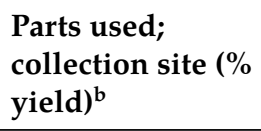 & $\begin{array}{l}\text { Bioactive or } \\
\text { potentially bioactive } \\
\text { components }\end{array}$ & Biological activities \\
\hline $\begin{array}{l}\text { Vitex thyrsiflora } \\
\text { Baker (Verbenaceae) } \\
\text { 34861/HNC } \\
\text { Ndombi }\end{array}$ & $\begin{array}{l}\text { Treatment of orchitis, } \\
\text { stomach pains, } \\
\text { sterility and parasitic } \\
\text { infections [13] }\end{array}$ & $\begin{array}{l}\text { Leaves, Melong, } \\
\text { Cameroon (15\%) }\end{array}$ & Not reported & $\begin{array}{l}\text { Antihyperglycemic } \\
\text { and antioxidant } \\
\text { potential of ethanol } \\
\text { extract of Vitex } \\
\text { thyrsiflora leaves [14] }\end{array}$ \\
\hline
\end{tabular}




$\begin{array}{ll}\begin{array}{l}\text { Entandrophragma } \\ \text { cylindricum }\end{array} & \begin{array}{l}\text { Treatment of } \\ \text { rheumatism, } \\ \text { (Sprague) Sprague }\end{array} \\ \text { (Meliaceae) } & \text { bronchitis, lung } \\ \text { complaints, colds, } \\ \text { 54965/SFRCAM } & \text { edema, malaria, } \\ \text { Asseng-Assie } & \text { yellow fever, typhoid } \\ & \begin{array}{l}\text { fever, diarrhea and } \\ \text { stomachache [15] }\end{array}\end{array}$

Anonidium mannii (Oliv.) Engl. \& Diels (Annonaceae) 1918/SRFK Ebon

Spider and snake bites, bronchitis, dysenteria, gastroenteritis, syphilis [22],
Stem barks, Mount Kalla, Cameroon (14.05\%)

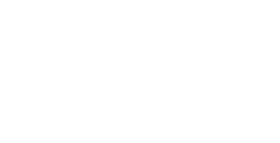
diarrhea, malaria, Cancer Diabetes and arterial hypertension [23]
Stem barks, Babimbi II, Cameroon (9.26\%)
Sapelenins G-J, (+)-7',7'-dimethyl-Shydroxy-2R,3S-transpubeschin,

sapelenins A-D, sapelenins E-F [16], [17], ekeberin D2 [18], (+)-catechin, epicatechin and anderolide G [19]
Prenylated bisindole alkaloids

(Annonidine A-E)

[24]

\author{
Anti-inflammatory \\ activities of the \\ sapelenins G-J by \\ suppressing the \\ secretion of IL-17 by \\ phytohemagglutinin- \\ stimulated human \\ peripheral blood \\ mononuclear cells \\ [20]. Antisickling, \\ antihemolytic and \\ radical scavenging \\ activities of essential \\ oil, methanol, and \\ aqueous extracts \\ [21]. \\ Antiplasmodial \\ activity of methanol, \\ ethyl acetate and \\ aqueous against \\ chloroquino- \\ sensitive 3D7 and \\ chloroquino- \\ resistant INDO \\ strains of \\ Plasmodium \\ falciparum; \\ antioxidant activity \\ of these extracts [15] \\ Not reported
}

${ }^{a}(\mathrm{HNC})$, Cameroon National Herbarium; (SRFCAM), Société des Réserves Forestières du Cameroun. b Yield calculated as the ratio of the mass of the obtained ethanol extract/mass of the plant powder.

\section{Preparation of the crude extracts}

The dried leaves of $V$. thyrsiflora $(2 \mathrm{~kg})$, and stem barks of E. cylindricum $(2 \mathrm{~kg})$ and A. mannii (2 kg) were macerated at room temperature in ethanol $(5 \mathrm{~L}, 72 \mathrm{~h})$ to obtain the crude extracts $(300,281,185.1 \mathrm{~g}$, respectively) after evaporation of ethanol under vacuum using a rotary evaporator (Büchi R200). The yields of the extraction were $15 \%, 14.05 \%$, and $9.26 \%(\mathrm{w} / \mathrm{w})$ respectively.

\section{Phytochemical screening}

All extracts were subjected to phytochemical analysis for the identification of plant bioactive constituents (alkaloids, flavonoids, glycosides, carbohydrates, tannins, resins, steroids, proteins, and amino acids) using standard methods as earlier described by Khandelwal [25].

\section{Experimental animals}

Nulliparous and non-pregnant Wistar rats (180-200 g) used in this study were housed in plastic cages under standard laboratory conditions $\left(12 \mathrm{~h}\right.$ light/dark cycle: $\left.25 \pm 2{ }^{\circ} \mathrm{C}\right)$ for 7 days prior to the commencement of the experiments. All animals were given food and water ad libitum. 


\section{Ethical guidelines}

Experimental animals were handled in accordance with the prescription of the Committee for the Purpose of Control and Supervision of Experiments on Animals (CPCSEA) issued by the Ministry of Environment and Forests, Government of India. The animal study was carried out at VNS Group of Institutions, Faculty of Pharmacy, Bhopal (Madhya Pradesh) with the permission of the Institutional Animal Ethics Committee (Registration No. 778/PO/a/03/CPCSEA; 03.09).

\section{Chemicals and drugs}

Chemicals used included carrageenan, acetic acid, egg albumin, hydrogen peroxide, and brewer's yeast. Other chemicals were Dragendorff's reagent, Mayer's reagent, Benedict's reagent, Folin-Ciocalteu, catechin, ascorbic acid, 2,21-azinobis-(3-ethylbenthialozine)-6-sulfonic acid (ABTS), and 1,1-diphenyl-2-picrylhydrazyl (DPPH), 2,4,6-tri[2-pyridyl]-s-triazine (TPTZ). The standard drugs used were diclofenac sodium, indometacin, and aspirin. All chemicals and drugs used were of analytical grade and purchased from Sigma-Aldrich (St. Louis, MO, USA).

\section{Acute oral toxicity}

Acute oral toxicity was carried out as earlier described [26]. Three groups of six animals each were administered as follows: the control group received water $(1 \mathrm{~mL} / 100 \mathrm{~g} \mathrm{bw})$, while the two test groups received plant extracts (1000 and $2000 \mathrm{mg} / \mathrm{kg} \mathrm{bw}$ ). Animals were then observed for toxic manifestations for the next $5 \mathrm{~h}$ and subsequently observed intermittently for signs of morbidity and mortality for 7 days.

\section{Determination of total phenolic content}

TPC was estimated by the Folin-Ciocalteu method [27]. Twenty microliters of extract $(0.625-10 \mathrm{mg} / \mathrm{mL})$ were added to $0.4 \mathrm{~N}$ Folin-Ciocalteu reagent $(980 \mu \mathrm{L})$. Catechin $(10-80 \mu \mathrm{M})$ was used as a standard for the calibration curve $\left(y=0.0066 x+0.0030 ; r^{2}=0.9978\right)$. Absorbance at $760 \mathrm{~nm}$ was measured after 10 min of incubation at room temperature.

\section{Determination of total flavonoid content}

TFC was determined by the colorimetric method [28]. Of the extract, $0.1 \mathrm{~mL}(0.625-10 \mathrm{mg} / \mathrm{mL})$ was mixed with $5 \%(\mathrm{w} / \mathrm{v})$ sodium nitrite $(0.2 \mathrm{~mL})$. After $5 \mathrm{~min}, 10 \%(\mathrm{w} / \mathrm{v})$ aluminum chloride $(0.2 \mathrm{~mL})$ and $1 \mathrm{M} \mathrm{NaOH}(2 \mathrm{~mL})$ were added. Catechin $(50-600 \mu \mathrm{M})$ was used as a standard for the calibration curve $\left(\mathrm{y}=0.0002 \mathrm{x}-0.0033 ; \mathrm{r}^{2}=\right.$ 0.9828). Absorbance was measured at $510 \mathrm{~nm}$.

\section{Determination of ferric reducing antioxidant power (FRAP)}

FRAP was performed by the method of Benzie and Strain [29]. FRAP reagent was prepared with $300 \mathrm{mM}$ acetate buffer $\mathrm{pH} \pm 3.6(100 \mathrm{~mL}), 10 \mathrm{mM}$ 2,4,6-tripyridyl-s-triazine $(10 \mathrm{~mL})$, and $20 \mathrm{mM} \mathrm{FeCl}{ }_{3}, \mathrm{H}_{2} \mathrm{O}(10 \mathrm{~mL})$. Seventyfive microliters of the extract $(0.625-10 \mathrm{mg} / \mathrm{mL})$ were added to the FRAP reagent $(2 \mathrm{~mL})$, and the mixture was incubated at room temperature for $15 \mathrm{~min}$. Catechin $(50-600 \mu \mathrm{M})$ was used as a standard for the calibration curve $\left(\mathrm{y}=0.0021 \mathrm{x}-0.0154 ; \mathrm{r}^{2}=0.9984\right)$. Absorbance was measured at $593 \mathrm{~nm}$.

\section{Determination of DPPH free radical scavenging activity}

Free radical scavenging activity of the extracts on the stable radical DPPH was estimated by the method of Mensor et al. [30]. One hundred microliters of the extract $(0.25-4 \mathrm{mg} / \mathrm{mL})$ were mixed with $1900 \mu \mathrm{L}$ of DPPH methanol solution $(30 \mathrm{mg} / \mathrm{L}$ ) and kept for $30 \mathrm{~min}$ at room temperature in a dark cupboard. The decrease in the solution absorbance, due to proton donating of substances was measured at $517 \mathrm{~nm}$. L-Ascorbic acid (15.62-250 
$\mu \mathrm{g} / \mathrm{mL}$ ) was used as positive control. The percentage of DPPH radical scavenging activity was calculated using the following formula:

DPPH radical scavenging activity $(\%)=\left[\left(\mathrm{A}_{\text {control }}-\mathrm{A}_{\text {sample }}\right) / \mathrm{A}_{\text {control }}\right] \times 100$

\section{Determination of hydrogen peroxide radical scavenging activity}

Hydrogen peroxide scavenging activity of the extracts was determined using the method described by Rutch et al. [31]. A solution of hydrogen peroxide $(40 \mathrm{mM})$ was prepared in phosphate buffer (pH7.4). Hydrogen peroxide solution $(0.6 \mathrm{~mL})$ was mixed with $1.4 \mathrm{~mL}$ of extract $(0.625-10 \mathrm{mg} / \mathrm{mL})$. The absorbance of hydrogen peroxide at $230 \mathrm{~nm}$ was determined after $10 \mathrm{~min}$ of incubation against a blank solution containing phosphate buffer without hydrogen peroxide. L-Ascorbic acid $(10-80 \mu \mathrm{g} / \mathrm{mL})$ was used as the reference standard. The percentage of $\mathrm{H}_{2} \mathrm{O}_{2}$ scavenging activity was calculated using the following formula:

$$
\mathrm{H}_{2} \mathrm{O}_{2} \text { scavenging activity }(\%)=\left[\left(\mathrm{A}_{\text {control }}-\mathrm{A}_{\text {sample }}\right) / \mathrm{A}_{\text {control }}\right] \times 100
$$

\section{Determination of ABTS radical scavenging activity}

2,2'-Azinobis(3-ethylbenzothiazoline 6-sulfonic acid) $\left(\mathrm{ABTS}^{+}\right)$scavenging effect of the extracts was analyzed in accordance with the method of Re et al. [32]. ABTS radical was generated by mixing equal volumes of $7 \mathrm{mM}$ of ABTS and $4.9 \mathrm{mM}$ of potassium permanganate $\left(\mathrm{KMnO}_{4}\right)$ and kept in the dark room for $24 \mathrm{~h}$. Eight milliliters of the ABTS generated radical solution was diluted further in $72 \mathrm{~mL}$ of distilled water. One milliliter of the diluted radical solution was added to $20 \mu \mathrm{l}$ of plant extract $(0.625-10 \mathrm{mg} / \mathrm{mL})$, and the optical density read at $734 \mathrm{~nm}$ after $12 \mathrm{~min}$ of incubation. L-Ascorbic acid $(15.62-250 \mu \mathrm{g} / \mathrm{mL})$ was used as positive control.

$$
\text { ABTS scavenging activity }(\%)=\left[\left(\mathrm{A}_{\text {control }}-\mathrm{A}_{\text {sample }}\right) / \mathrm{A}_{\text {control }}\right] \times 100
$$

\section{Anti-inflammatory activity}

\section{Protein denaturation}

The protein denaturation method earlier described by Padmanabhan [33] was used for the determination of anti-inflammatory activity of the extracts. A standard NSAID, diclofenac sodium was used as the control drug. The reaction mixture contained $2 \mathrm{~mL}$ of extract or standard at varying concentrations $(50-1000 \mu \mathrm{g} / \mathrm{mL})$, phosphate buffer saline pH $6.4(2.8 \mathrm{~mL})$, and $5 \%$ egg albumin $(2 \mathrm{~mL})$. This was incubated at $27^{\circ} \mathrm{C}$ for $15 \mathrm{~min}$ after which denaturation was induced by raising the reaction temperature to $70{ }^{\circ} \mathrm{C}$ in a water bath for $10 \mathrm{~min}$. The reaction mixture was then allowed to cool to room temperature and the absorbance measured at $660 \mathrm{~nm}$ using double distilled water as blank. Each extract was analyzed in triplicate. The formula below was used to calculate the percentage inhibition of protein denaturation.

$$
\text { Inhibition of protein denaturation }(\%)=\left[\left(\mathrm{A}_{\text {sample }}-\mathrm{A}_{\text {control }}\right) / \mathrm{A}_{\text {control }}\right] \times 100
$$

\section{Erythrocyte membrane stabilization}

The effect of extract on membrane-stabilizing was evaluated using hypotonic solution-induced hemolysis [34]. Whole blood collected from anesthetized rats through orbital puncture was washed until the supernatant was 
clear with an isotonic solution $(154 \mathrm{mM} \mathrm{NaCl})$ through centrifugation at $3000 \mathrm{rpm}$. The erythrocyte (precipitate) was measured and reconstituted as a $40 \%(\mathrm{v} / \mathrm{v})$ suspension with isotonic buffer solution (10 mM sodium phosphate buffer $\mathrm{pH} 7.4$ ) and kept as the stock red blood cells suspension (RBCs). The reaction mixture was made up of RBCs $(0.25 \mathrm{~mL}), 2.5 \mathrm{~mL}$ of hypotonic solution $(5 \mathrm{mM} \mathrm{NaCl})$ in $10 \mathrm{mM}$ sodium phosphate-buffered saline (pH 7.4), and $0.25 \mathrm{~mL}$ of the extracts or indometacin at a different concentration range $(50-1000 \mu \mathrm{g} / \mathrm{mL}$ ). The control sample consisting of $0.25 \mathrm{~mL}$ of RBCs was mixed with hypotonic buffered saline alone. This was incubated at room temperature for $10 \mathrm{~min}$ and then centrifuged at $3000 \mathrm{rpm}$. The absorbance of the supernatant was measured at $540 \mathrm{~nm}$. Each sample was analyzed in triplicate. The percentage inhibition of hemolysis or membrane stabilization was calculated using the following equation:

$$
\text { Inhibition of hemolysis }(\%)=\left[1-\left(\mathrm{A}_{2}-\mathrm{A}_{1}\right) /\left(\mathrm{A}_{3}-\mathrm{A}_{1}\right)\right] \times 100
$$

where:

$\mathrm{A}_{1}=$ test sample in isotonic solution

$\mathrm{A}_{2}=$ test sample in hypotonic solution

$\mathrm{A}_{3}=$ control sample in hypotonic solution

\section{Carrageenan-induced paw edema}

Paw edema was induced by intraperitoneal injection of $0.1 \mathrm{~mL}$ of carrageenan suspension $(1 \% \mathrm{w} / \mathrm{v})$ into the sub-plantar region of the right hind paw of the rats [35]. One hour prior to the carrageenan injection, five groups of six rats each were orally treated with distilled water $(10 \mathrm{~mL} / \mathrm{kg} \mathrm{bw})$, indometacin $(10 \mathrm{mg} / \mathrm{kg} \mathrm{bw})$, and extract (200 and $400 \mathrm{mg} / \mathrm{kg} \mathrm{bw}$ ). At intervals before, and after 1, 2, 3, 4, and $5 \mathrm{~h}$ following the carrageenan injection, paw edema was measured by the displacement technique using a Vernier caliper to find out the circumference of paw edema. Total edema developed during this period was monitored as the area under the time-course curve (AUC). The inhibitory activity was calculated according to the formula:

Inhibition of paw edema $(\%)=\left[\left(C_{t}-C_{o}\right)_{\text {control }}-\left(C_{t}-C_{o}\right)_{\text {treated }} /\left(C_{t}-C_{o}\right)_{\text {control }}\right] \times 100$

where:

$\mathrm{C}_{\mathrm{t}}=$ paw circumference at time $\mathrm{t}$

$\mathrm{C}_{\mathrm{O}}=$ paw circumference before carrageenan injection

$\left(C_{t}-C_{o}\right)=$ edema or change in paw size after time $t$.

\section{Analgesic activity}

The peripheral analgesic activity of the extracts was assessed in acetic acid-induced abdominal writhing in Albino rats as described by Veerappan et al. [36]. This method is characterized by abdominal constriction writhing from the intraperitoneal injection of acetic acid $(10 \mathrm{~mL} / \mathrm{kg}$ of $0.6 \% \mathrm{v} / \mathrm{v}$ glacial acetic acid solution in normal saline). Groups of six rats each were orally administered distilled water $(10 \mathrm{~mL} / \mathrm{kg} \mathrm{bw})$, diclofenac sodium $(100 \mathrm{mg} / \mathrm{kg} \mathrm{bw})$, and extract (200 and $400 \mathrm{mg} / \mathrm{kg} \mathrm{bw})$. Thirty minutes after the acetic acid solution was administered, the number of writhing was counted for the next $15 \mathrm{~min}$. The percentage inhibition of writhing was calculated using the formula below:

$$
\text { Inhibition of writhing }(\%)=\left[\left(\mathrm{M}_{\text {control }}-\mathrm{M}_{\text {sample }} / \mathrm{M}_{\text {control }}\right)\right] \times 100
$$

where $\mathrm{M}=$ mean number of writhing.

\section{Antipyretic activity}

The antipyretic activity was characterized by a fever-induced by subcutaneous injection of $10 \mathrm{~mL} / \mathrm{kg}$ of $20 \%$ $\mathrm{w} / \mathrm{v}$ suspension of brewer's yeast in normal saline [37]. Animals whose rectal temperature increased by at least $0.5^{\circ} \mathrm{C}$ after $18 \mathrm{~h}$ of yeast injection were included in the study. The normal rectal temperature of each animal was measured using a digital thermometer. The animals were randomly divided into four groups of six animals and 
treated as follows: distilled water $(10 \mathrm{~mL} / \mathrm{kg}$ bw), aspirin (100 mg/kg bw), and extract (200 and $400 \mathrm{mg} / \mathrm{kg}$ bw). The rectal temperature was again recorded at time intervals of 1, 2, 3, 4, and $5 \mathrm{~h}$ after extract administration. Rectal temperature reduction for each treatment was calculated in the arbitrary unit as the area under the curve (AUC).

\section{Statistical analysis}

Data were expressed as mean \pm SD. Statistical analysis was carried out using one-way analysis of variance (ANOVA) followed by Student-Newman-Keuls Multiple comparison test using SPSS 16.0 Windows software. Differences between values were considered significant at $\mathrm{p}<0.05$.

\section{Results}

\section{Phytochemical screening}

Phytochemical screening of the various extracts revealed the presence of bioactive constituents (Table 2). Except for proteins and amino acids, all other chemical compounds are present in all crude extracts. However, flavonoids, glycosides, and tannins were low in EtOHVT. Flavonoids and alkaloids were low in EtOHAM and EtOHEC, respectively.

Table 2: Chemical constituents of the studied plant ethanol extracts.

\begin{tabular}{|c|c|c|c|c|}
\hline Phytoconstituents & Identification tests & $\begin{array}{l}\text { Observations } \\
\text { V. thyrsiflora }\end{array}$ & E.cylindricum & A. mannii \\
\hline \multirow[t]{2}{*}{ Alkaloids } & Dragendorff's test & ++ & + & +++ \\
\hline & Mayer's test & ++ & + & +++ \\
\hline \multirow[t]{2}{*}{ Flavonoids } & Lead acetate test & + & +++ & + \\
\hline & Shinoda's test & + & +++ & + \\
\hline \multirow[t]{3}{*}{ Glycosides } & Raymond's test & + & +++ & ++ \\
\hline & Killer Killani's test & + & +++ & ++ \\
\hline & Legal test & + & +++ & ++ \\
\hline \multirow[t]{3}{*}{ Carbohydrates } & Molisch's test & +++ & +++ & +++ \\
\hline & Fehling's test & +++ & +++ & +++ \\
\hline & Benedict's test & +++ & +++ & +++ \\
\hline \multirow[t]{2}{*}{ Tannins } & Vanillin- $\mathrm{HCl}$ test & + & +++ & +++ \\
\hline & Gelatin test & + & +++ & +++ \\
\hline \multirow[t]{2}{*}{ Resins } & Ferric chloride test & +++ & +++ & +++ \\
\hline & Turbidity test & +++ & +++ & +++ \\
\hline \multirow[t]{2}{*}{ Steroids } & $\begin{array}{l}\text { Liebermann- } \\
\text { Buchard's } \\
\text { test }\end{array}$ & +++ & ++ & +++ \\
\hline & Salkowski's test & +++ & ++ & +++ \\
\hline \multirow{3}{*}{$\begin{array}{l}\text { Proteins and amino } \\
\text { acids }\end{array}$} & Biuret test & - & - & - \\
\hline & Precipitation test & - & - & - \\
\hline & Ninhydrin test & - & - & - \\
\hline
\end{tabular}

- , absent; +, present at low concentration; ++ , present at moderate concentration; +++, present at high concentration.

\section{Antioxidant activity}

TPC, TFC, and FRAP of studied plant extracts ranged from 15.93 to $64.45 \mathrm{CA} \mathrm{mg} / \mathrm{g}, 336.03$ to $1053.48 \mathrm{CA} \mathrm{mg} / \mathrm{g}$, and 288.75 to $364.91 \mathrm{CA} \mathrm{mg/g}$, respectively (Table 3). The highest concentration of phenolics, flavonoids, and reducing power was found in EtOHEC (64.45 CA mg/g), EtOHAM (1053.48 CA mg/g), and EtOHVT (364.91 CA mg/g), while the lowest contents were recorded in EtOHAM (15.93 CA mg/g), EtOHVT (336.03 CA mg/g), and EtOHAM (288.75 CA mg/g), respectively. All extracts showed good DPPH, $\mathrm{H}_{2} \mathrm{O}_{2}$, and ABTS scavenging 
activities (Figure 1 and Table 3) with $\mathrm{IC}_{50}$ values ranging from 0.30 to $1.65 \mu \mathrm{g} / \mathrm{mL}, 1.40$ to $3.55 \mu \mathrm{g} / \mathrm{mL}$, and 0.52 to $1.90 \mu \mathrm{g} / \mathrm{mL}$, respectively, although weak when compared to those of ascorbic acid $(0.05-0.63 \mu \mathrm{g} / \mathrm{mL})$. A great scavenging action reflects a higher antioxidant activity and a lower $\mathrm{IC}_{50}$. The $\mathrm{IC}_{50}$ values of extracts decreased in the following order: EtOHEC $>$ EtOHVT $>$ EtOHAM $>$ ascorbic acid.

Table 3: Antioxidant activities of the studied plant ethanol extracts.

\begin{tabular}{lrrrrrr}
\hline Extracts & TPC & TFC & FRAP & DPPH & $\mathbf{H}_{2} \mathbf{O}_{2}$ & ABTS \\
\hline V. thyrsiflora & $32.97 \pm 1.32^{\mathrm{b}}$ & $336.03 \pm 7.49^{\mathrm{c}}$ & $364.91 \pm 2.85^{\mathrm{a}}$ & $0.30 \pm 0.01^{\mathrm{b}}$ & $1.40 \pm 0.03^{\mathrm{b}}$ & $0.52 \pm 0.03^{\mathrm{b}}$ \\
E. cylindricum & $64.45 \pm 1.73^{\mathrm{a}}$ & $458.12 \pm$ & $325.38 \pm 1.84^{\mathrm{b}}$ & $1.65 \pm 0.04^{\mathrm{d}}$ & $3.55 \pm 0.09^{\mathrm{c}}$ & $1.90 \pm 0.05^{\mathrm{d}}$ \\
& & $20.17^{\mathrm{b}}$ & & & & \\
A. mannii & $15.93 \pm 1.27^{\mathrm{c}}$ & $1053.48 \pm$ & $288.75 \pm 2.96^{\mathrm{c}}$ & $0.67 \pm 0.02^{\mathrm{c}}$ & $1.81 \pm 0.07^{\mathrm{b}}$ & $0.84 \pm 0.01^{\mathrm{c}}$ \\
Ascorbic acid & & $43.81^{\mathrm{a}}$ & & $0.05 \pm 0.03^{\mathrm{a}}$ & $0.63 \pm 0.02^{\mathrm{a}}$ & $0.05 \pm 0.02^{\mathrm{a}}$ \\
\hline
\end{tabular}

$\mathrm{a}, \mathrm{b}, \mathrm{c}, \mathrm{d}$ In the same column, values carrying different letters in superscript are significantly different at $\mathrm{p}<0.05$ (Student-Newman-Keuls test). TPC, total phenolic content; TFC, total flavonoid content; FRAP, ferric reducing antioxidant power expressed in mg catechin equivalent/g by dry weight (CA mg/g). DPPH, $\mathrm{H}_{2} \mathrm{O}_{2}$, and ABTS expressed in inhibitory concentration $50(\mu \mathrm{g} / \mathrm{mL}$ ).

\section{Anti-inflammatory activity}

Protein denaturation was inhibited by all the extracts studied in a concentration-dependent manner (Table 4) with percentage inhibition between 53.94\% and 82.27\% (EtOHVT), 11.39 and 76.34\% (EtOHEC), and 6.79 and $77.47 \%$ (EtOHAM). Diclofenac sodium had the maximum percentage of inhibition (78.22-97.53\%). The protein denaturation inhibitory effects of the extracts decreased in the following order: Diclofenac sodium $>$ EtOHVT $>$ EtOHEC > EtOHAM.

Table 4: Effect of the studied plant ethanol extracts on protein denaturation and RBCs hemolysis.

\begin{tabular}{|c|c|c|c|c|c|}
\hline & \multicolumn{5}{|c|}{ Concentration $(\mu \mathrm{g} / \mathrm{mL})$} \\
\hline & 1000 & 500 & 200 & 100 & 50 \\
\hline \multicolumn{6}{|c|}{ Inhibition of protein denaturation (\%) } \\
\hline V. thyrsiflora & $82.27 \pm 0.13^{b}$ & $79.85 \pm 5.45^{\mathrm{a}}$ & $64.79 \pm 3.28^{\mathrm{b}}$ & $59.25 \pm 1.53^{\mathrm{b}}$ & $53.94 \pm 7.25^{\mathrm{b}}$ \\
\hline E. cylindricum & $76.34 \pm 6.77^{\mathrm{b}}$ & $42.31 \pm 8.60^{\mathrm{b}}$ & $20.92 \pm 3.50^{c}$ & $14.51 \pm 2.70^{c}$ & $11.39 \pm 1.48^{c}$ \\
\hline A. mannii & $77.47 \pm 6.35^{\mathrm{b}}$ & $37.67 \pm 9.40^{\mathrm{b}}$ & $19.07 \pm 6.22^{c}$ & $9.72 \pm 2.63^{\mathrm{cd}}$ & $6.79 \pm 5.81^{c}$ \\
\hline $\begin{array}{l}\text { Diclofenac } \\
\text { sodium }\end{array}$ & $94.53 \pm 8.45^{\mathrm{a}}$ & $84.46 \pm 3.45^{\mathrm{a}}$ & $82.43 \pm 2.34^{\mathrm{a}}$ & $81.18 \pm 1.28^{\mathrm{a}}$ & $78.22 \pm 1.02^{\mathrm{a}}$ \\
\hline \multicolumn{6}{|c|}{ Inhibition of hemolysis (\%) } \\
\hline V. thyrsiflora & $88.00 \pm 2.87^{b}$ & $70.27 \pm 3.55^{\mathrm{b}}$ & $50.19 \pm 4.08^{\mathrm{b}}$ & $37.77 \pm 5.67^{\mathrm{b}}$ & $21.18 \pm 2.71^{\mathrm{b}}$ \\
\hline E. cylindricum & $78.13 \pm 1.05^{c}$ & $42.76 \pm 7.34^{\mathrm{d}}$ & $39.61 \pm 0.37^{c}$ & $28.30 \pm 0.67^{c}$ & $19.26 \pm 1.81^{\mathrm{b}}$ \\
\hline A. mannii & $79.35 \pm 1.96^{c}$ & $56.91 \pm 0.97^{c}$ & $37.23 \pm 1.51^{\mathrm{cd}}$ & $24.41 \pm 0.23^{c}$ & $18.90 \pm 0.23^{b}$ \\
\hline Indometacin & $95.34 \pm 4.27^{\mathrm{a}}$ & $86.14 \pm 9.19^{a}$ & $71.66 \pm 6.65^{\mathrm{a}}$ & $56.74 \pm 4.83^{\mathrm{a}}$ & $44.87 \pm 3.12^{\mathrm{a}}$ \\
\hline
\end{tabular}

$a, b, c, d$ For the same concentration, values carrying different letters in superscript are significantly different at $\mathrm{p}<0.05$ (Student-Newman-Keuls test).

At the different concentrations tested, all the extracts protected the erythrocyte membrane against lysis induced by hypotonic solution (Table 4) with the inhibition percentage of hemolysis being between $21.18 \%$ and 88.00\% (EtOHVT), 19.26\% and 78.13\% (EtOHEC), and 18.90\% and 79.35\% (EtOHAM). Indometacin (44.87$95.34 \%$ ) exerted a higher inhibitory effect than plant extracts. Inhibitory effects of the extracts decreased in the following order: indometacin > EtOHVT > EtOHEC > EtOHAM.

The injection of carrageenan in the control group caused edema, which increased gradually until it reaches a maximum size of $0.234 \mathrm{~mm}$ after $5 \mathrm{~h}$. Earlier administration, the effect of the reference drug (indometacin) resulted in significant inhibition of the development of edema in a progressive manner (Table 5). The inhibitory effect of indometacin $(10 \mathrm{mg} / \mathrm{kg})$ occurred in the first hour after carrageenan injection and was maintained at almost the same level for $5 \mathrm{~h}$, with inhibition percentages ranging from $63.95 \%$ to $83.89 \%$. Pre-treatment of the rats with the ethanol extracts resulted in a dose-dependent reduction of edema with inhibition percentages ranging between $10.25 \%$ and $32.55 \%$ (EtOHVT), 6.86\% and 43.89\% (EtOHEC), and 13.67\% and 34.74\% (EtO- 
HAM) at $200 \mathrm{mg} / \mathrm{kg}$ bw; $21.31 \%$ and $41.86 \%$ (EtOHVT), $16.66 \%$ and $46.61 \%$ (EtOHEC), and $10.65 \%$ and $67.44 \%$ (EtOHAM) at $400 \mathrm{mg} / \mathrm{kg}$ bw. The inhibitory activity of EtOHAM at $400 \mathrm{mg} / \mathrm{kg}$ bw (67.44\%) was greater than indometacin $(63.95 \%)$ after $1 \mathrm{~h}$.

Table 5: Effect of the studied plant ethanol extracts on carrageenan-induced rat paw edema.

\begin{tabular}{|c|c|c|c|c|c|c|}
\hline \multirow[t]{2}{*}{ Treatment } & \multicolumn{6}{|c|}{ Edema or change in paw size after time $t(\mathrm{~mm})$ and $\%$ inhibition } \\
\hline & Dose (mg/kg) & $1 \mathrm{~h}$ & $2 \mathrm{~h}$ & $3 \mathrm{~h}$ & $4 \mathrm{~h}$ & $5 \mathrm{~h}$ \\
\hline Control & - & $0.17 \pm 0.05$ & $0.21 \pm 0.05$ & $0.23 \pm 0.04$ & $0.20 \pm 0.06$ & $0.23 \pm 0.04$ \\
\hline Indometacin & 10 & $\begin{array}{r}0.06 \pm 0.03^{\mathrm{a}} \\
(63.95)\end{array}$ & $\begin{array}{r}0.06 \pm 0.03^{\mathrm{a}} \\
(71.69)\end{array}$ & $\begin{array}{r}0.05 \pm 0.03^{\mathrm{b}} \\
(76.27)\end{array}$ & $\begin{array}{r}0.05 \pm 0.03^{\mathrm{a}} \\
(83.89)\end{array}$ & $\begin{array}{r}0.05 \pm 0.03^{\mathrm{b}} \\
(76.22)\end{array}$ \\
\hline V. thyrsiflora & 200 & $\begin{array}{r}0.11 \pm 0.07 \\
(32.55)\end{array}$ & $\begin{array}{r}0.15 \pm 0.09 \\
(29.24)\end{array}$ & $\begin{array}{r}0.18 \pm 0.10 \\
(22.03)\end{array}$ & $\begin{array}{r}0.16 \pm 0.09 \\
(19.60)\end{array}$ & $\begin{array}{r}0.21 \pm 0.12 \\
(10.25)\end{array}$ \\
\hline & 400 & $\begin{array}{r}0.10 \pm 0.02 \\
(41.86)\end{array}$ & $\begin{array}{r}0.14 \pm 0.03 \\
(32.07)\end{array}$ & $\begin{array}{r}0.15 \pm 0.04 \\
(35.59)\end{array}$ & $\begin{array}{r}0.15 \pm 0.06 \\
(23.52)\end{array}$ & $\begin{array}{r}0.19 \pm 0.02 \\
(21.31)\end{array}$ \\
\hline E. cylindricum & 200 & $\begin{array}{r}0.11 \pm 0.05 \\
(34.88)\end{array}$ & $\begin{array}{r}0.12 \pm 0.08 \\
(43.39)\end{array}$ & $\begin{array}{r}0.21 \pm 0.07 \\
(11.01)\end{array}$ & $\begin{array}{r}0.19 \pm 0.09 \\
(6.86)\end{array}$ & $\begin{array}{r}0.17 \pm 0.07 \\
(25.64)\end{array}$ \\
\hline & 400 & $\begin{array}{r}0.09 \pm 0.01 \\
(46.51)\end{array}$ & $\begin{array}{r}0.11 \pm 0.04 \\
(46.22)\end{array}$ & $\begin{array}{r}0.12 \pm 0.04 \\
(46.61)\end{array}$ & $\begin{array}{r}0.17 \pm 0.05 \\
(16.66)\end{array}$ & $\begin{array}{r}0.18 \pm 0.06 \\
(26.22)\end{array}$ \\
\hline A. mannii & 200 & $\begin{array}{r}0.12 \pm 0.04 \\
(30.23)\end{array}$ & $\begin{array}{r}0.15 \pm 0.07 \\
(25.47)\end{array}$ & $\begin{array}{r}0.15 \pm 0.03 \\
(34.74)\end{array}$ & $\begin{array}{r}0.15 \pm 0.07 \\
(26.47)\end{array}$ & $\begin{array}{r}0.20 \pm 0.06 \\
(13.67)\end{array}$ \\
\hline & 400 & $\begin{array}{r}0.05 \pm 0.03^{\mathrm{b}} \\
(67.44)\end{array}$ & $\begin{array}{r}0.10 \pm 0.04 \\
(49.05)\end{array}$ & $\begin{array}{r}0.15 \pm 0.04 \\
(36.44)\end{array}$ & $\begin{array}{r}0.17 \pm 0.05 \\
(13.72)\end{array}$ & $\begin{array}{r}0.21 \pm 0.04 \\
(10.65)\end{array}$ \\
\hline
\end{tabular}

${ }^{\mathrm{a}} \mathrm{p}<0.05,{ }^{\mathrm{b}} \mathrm{p}<0.001,{ }^{\mathrm{c}} \mathrm{p}<0.01$, compared to control group (water), $\mathrm{n}=6$ (Student-Newman-Keuls test), mean $\pm \mathrm{SD}$.

\section{Analgesic activity}

Acetic acid injection intraperitoneally caused 41 abdominal writhings within $15 \mathrm{~min}$ in the control group (Table 6). The extracts significantly inhibited the writhing in a dose-dependent manner with inhibition percentages ranging from $28.98 \%$ to $65.21 \%(200 \mathrm{mg} / \mathrm{kg})$ and $51.20 \%$ to $76.81 \%(400 \mathrm{mg} / \mathrm{kg})$. EtOHAM $(65.21 \%)$ showed a similar activity to diclofenac sodium $(65.70 \%)$ at $200 \mathrm{mg} / \mathrm{kg}$. The activity of EtOHAM $(76.81 \%)$ was better than diclofenac sodium at $400 \mathrm{mg} / \mathrm{kg}$. Inhibitory effects of the extracts against abdominal writhing decreased in the following order: EtOHAM > indometacin > EtOHVT > EtOHEC.

Table 6: Effect of the studied plant ethanol extracts on acetic acid-induced rat writhing reflex.

\begin{tabular}{lrrr}
\hline Treatment & Dose $\mathbf{( m g / k g )}$ & Number of writhing & \% inhibition \\
\hline Control & - & $41.40 \pm 9.81$ & 0.00 \\
Diclofenac sodium & 100 & $14.20 \pm 2.77^{\mathrm{a}}$ & 65.70 \\
V. thyrsiflora & 200 & $28.80 \pm 5.93^{\mathrm{b}}$ & 30.43 \\
& 400 & $19.00 \pm 6.00^{\mathrm{a}}$ & 54.10 \\
E. cylindricum & 200 & $29.40 \pm 2.96^{\mathrm{b}}$ & 28.98 \\
& 400 & $20.20 \pm 7.25^{\mathrm{a}}$ & 51.20 \\
A. mannii & 200 & $14.40 \pm 5.77^{\mathrm{a}, \mathrm{d}}$ & 65.21 \\
& 400 & $9.60 \pm 4.66^{\mathrm{a}}$ & 76.81 \\
\hline
\end{tabular}

${ }^{a} \mathrm{p}<0.001,{ }^{b} \mathrm{p}<0.01,{ }^{\mathrm{c}} \mathrm{p}<0.05$ compared to control group, ${ }^{\mathrm{d}} \mathrm{p}<0.01$ compared to treated group $(200 \mathrm{mg} / \mathrm{kg}), \mathrm{n}=6$

(Student-Newman-Keuls test), mean $\pm \mathrm{SD}$.

\section{Antipyretic activity}

Experimental rats showed an average increase in rectal temperature of $0.93^{\circ} \mathrm{C}$ after $18 \mathrm{~h}$ of yeast injection (Figure 2). The temperature gradually increased and reached a maximum $\left(2.15^{\circ} \mathrm{C}\right)$ after $4 \mathrm{~h}$ in the control group. In the group treated with the standard drug (aspirin), the rectal temperature of the animals returned to normal after 5 h. Except for EtOHVT at the dose of $200 \mathrm{mg} / \mathrm{kg}$, the other extracts significantly reduced the rectal temperature 
of the rats compared to the control group. EtOHAM showed a similar antipyretic effect ( $\mathrm{p}<0.001)$ to aspirin at $400 \mathrm{mg} / \mathrm{kg}$. There was a sharp decrease in rectal temperature $1 \mathrm{~h}$ after administration of EtOHAM at 400 $\mathrm{mg} / \mathrm{kg}$, which was further followed by a gradual decrease in the tendency up to $5 \mathrm{~h}$. Inhibitory effects of the extracts against fever decreased in the following order: aspirin > EtOHAM > EtOHEC > EtOHVT.
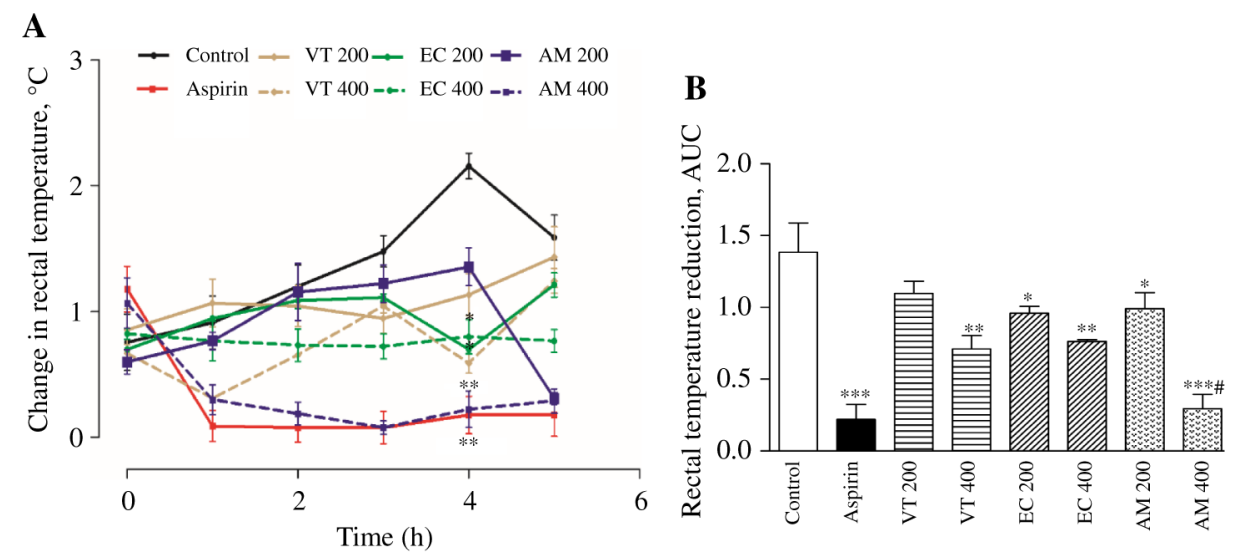

Figure 1: Effect of the studied plant ethanol extracts on time-course curves (A) and rectal temperature reduction (B) in the protocol of the brewer's yeast-induced rat pyrexia. ${ }^{*} \mathrm{p}<0.05,{ }^{* *} \mathrm{p}<0.01,{ }^{* * * *} \mathrm{p}<0.001$ compared to control; ${ }^{\#} \mathrm{p}<0.05$ compared to treated group (400 mg/kg), $\mathrm{n}=6$ (Student-Newman-Keuls), Mean \pm SD; VT 200: V. thyrsiflora (200 mg/kg), VT 400: V. thyrsiflora (400 mg/kg), EC 200: E. cylindricum (200 mg/kg), EC 400: E. cylindricum (400 mg/kg), AM 200: A. mannii (200 mg/kg), AM 400: A. mannii (400 mg/kg). All extracts reduced the rectal temperature of the rats compared to the control group.

\section{Discussion}

The identification of bioactive principles of medicinal plants is crucial for the standardization of herbal medicines. The presence of numerous biologically active secondary metabolites in the various plant extracts is responsible for their pharmacological properties. Several investigators reported the presence of these compounds in the Verbenaceae, Meliaceae, and Annonaceae families to which belong the studied plants [38]. Kuete et al. [23] working on the methanol extract of $A$. mannii leaves revealed the presence of alkaloids, steroids, and tannins and the absence of flavonoids. Ngnokam et al. [39] showed the presence of steroids in methylene chloride extract of the stem barks of E. cylindricum. Kopa et al. [14] revealed the presence of alkaloids, flavonoids, steroids, and glycosides in the ethanol extract of $V$. thyrsiflora and also steroids in the methanol-methylene chloride extract of the stem barks of $V$. thyrsiflora [40].

The TFC of the extracts was significantly higher than that of TPC, which was proportional to their reducing power. The TFC method involves hydrolysis, which liberates even bound flavonoids, unlike the TPC method that analyzes only free phenol compounds. Phenolic compounds act as antioxidants, radical scavengers, metal chelators, mediators, and enzyme inhibitors. They end free radical chain reactions by hydrogen transfer and by transforming these reactive species into more stable non-radical products. Some studies showed a correlation between phenolic content and antioxidant capacity [41], [42], [43]. Antioxidant activity was reported to increase proportionally with increased phenolic content [44]. Radical scavenging activity of the extracts may be due to their electron donor capacity by the DPPH as well as the $\mathrm{H}_{2} \mathrm{O}_{2}$ method. This could be explained by the difference in the stoichiometry of the reactions between antioxidant compounds in the extract and various radicals. Other factors such as radicals' stereoselectivity or differential solubility of the compounds (methanol for the DPPH test and distilled water for the $\mathrm{H}_{2} \mathrm{O}_{2}$ test) could also influence the ability of the extract to reduce different radicals when the latter contains a variety of antioxidants [45]. Although phenolic compounds possess an antioxidant potential, it is possible that antioxidant properties of the studied extracts are at least, in part, due to the presence of their non-phenolic compounds such as carbohydrates, alkaloids, and steroids. These compounds possess antioxidant activity by suppressing the initiation or propagation of chain reactions [46]. Catechin and its derivatives (epicatechin, anderolide $\mathrm{G}$ ) isolated from the stem bark of E. cylindricum were reported to be effective scavengers of ROS and may also function indirectly as antioxidants through their effects on transcription factors and enzyme activities [47].

Several anti-inflammatory drugs showed dose-dependent ability to inhibit thermally-induced protein denaturation. The mechanism of denaturation probably involved alteration of the electrostatic hydrogen, hydrophobic and disulfide bonding due to the inflammation response. The extracts could inhibit protein denaturation by interacting with amino acids that are exposed and denatured on heating such as lysine and 
threonine [48]. The erythrocyte membrane is a lysosomal membrane analog [43]. The lysosomal enzymes released during inflammation produce a variety of damage. The activity of these extracellular enzymes would be related to acute or chronic inflammation. There is evidence that these enzymes play an important role in the development of acute and chronic inflammation. Most anti-inflammatory drugs inhibit the release of these enzymes or stabilize the lysosomal membrane, which is one of the major events responsible for the inflammatory process [49]. Compounds with membrane-stabilizing properties are well known for their ability to interfere with the release of phospholipases that trigger the formation of inflammatory mediators [49]. All the extracts showed the membrane-stabilizing properties, which suggest that their anti-inflammatory activity observed in this study, may be related to the inhibition of the release of phospholipases that trigger the formation of inflammatory mediators. The induced inflammatory response is triphasic, characterized by the formation of marked edema resulting from the rapid production of several inflammation mediators. The first phase (90 $\mathrm{min}$ ) involves the release of histamine and serotonin; the second phase (90-150 min) is mediated by kinins (bradykinin), and the third phase (after $180 \mathrm{~min}$ ) by prostaglandins and nitric oxide produced by isoforms of cyclooxygenase and inducible NO synthase, respectively [50]. Although the actual mechanism of action of EtOHAM, EtOHEC, and EtOHVT in inflammation is unknown, these extracts inhibited the early phase of edema. The maximum anti-inflammatory activity occurred between $1 \mathrm{~h}$ and $2 \mathrm{~h}$ at the different doses tested. This suggests that these ethanol extracts would probably act by inhibiting the release and/or action of histamine, serotonin, and kinin. However, the exact mechanism needs to be established through further investigations. Secondary metabolites such as alkaloids, flavonoids, tannins, or steroids present in the three extracts, could be responsible for the observed anti-inflammatory activity [51]. Flavonoids may inhibit enzymes such as aldose reductase, xanthine oxidase, phosphodiesterase, $\mathrm{Ca}^{2+}$-ATPase, lipoxygenase, and cyclooxygenase; as well as other mediators of the inflammatory process, such as protein $C$ or adhesion of reactive molecules [52]. Steroids are known to attenuate inflammation by inhibiting phospholipase A2, which hydrolyzes arachidonic acid from membrane phospholipids, and the subsequent formation of prostanoids and leukotrienes through the pathways of cyclooxygenase and lipoxygenase and immune dysfunction in experimental models [53]. Kouam et al. [20] showed that the sapelenins G-J (acyclic triterpenoids) isolated from the stem barks of E. cylindricum, exhibit anti-inflammatory activities by suppressing the secretion of interleukin 17 by phytohemagglutinin-stimulated human peripheral blood mononuclear cells. Sapelenin G showed high activity comparable to reference cyclosporin A without any cytotoxic effects. Nakanishi et al. [54] reported that catechin reduces significantly the expression of pro-inflammatory cytokines (interleukin 6 and interleukin 8) and adhesion molecules (intercellular adhesion molecule-1 and vascular cell adhesion molecule-1) in human dental pulp cells stimulated with lipopolysaccharide or peptidoglycan. It also exhibits anti-inflammatory effects in BV-2 cells and 3T3-L1 adipocytes by suppressing the production of pro-inflammatory mediators (nitric oxide, tumor necrosis factor$\alpha$, and ROS) and mitigation of nuclear factor-kB through protein kinase B, extracellular signal-regulated kinase, p-38 mitogen-activated protein kinase, and adenosine monophosphate-activated protein kinase pathways [55], [56]. Catechins can stabilize the structure of the gastrointestinal micro-ecological environment via promoting the proliferation of beneficial intestinal bacteria and regulating the balance of intestinal flora, so as to relieve the inflammatory bowel disease [57]. Catechins could be also a key mediator in cardiovascular health via mechanisms of blood pressure reduction, flow-mediated vasodilation, and atherosclerosis attenuation [58].

It was suggested that acetic acid would act by releasing endogenous mediators that stimulate nociceptive neurons. Writhing is induced following activation of the local peritoneal receptor and involves prostanoid mediators. In rats, there is an increase in the peritoneal fluid of prostaglandins E2 and F2, as well as products of lipoxygenase, the release of sympathetic mediators of the nervous system. The nociceptive properties of acetic acid may also be due to the release of cytokines, such as nuclear factor-kB, tumor necrosis factor $\alpha$, interleukin $1 \beta$, and interleukin 8 , by peritoneal macrophages and resident mast cells [59]. The inhibitory effects on inflammatory pain and abdominal writhings produced after acetic acid administration may, therefore, be due to their ability to interfere with the activation of nociceptors by one of these endogenous mediators or to remove the sensitization of nociceptors to prostaglandins.

It was documented that yeast-induced fever increases the production of prostaglandins, which, in turn, stimulate the thermoregulatory center to increase body temperature [60]. The hypothermic activity of the extracts may be due to their action on cyclooxygenase 2, which would reduce the concentration of prostaglandin E2 in the brain or increase the inherent production of the body's own antipyretic substances such as arginine and vasopressin [61]. 


\section{Conclusions}

The present study demonstrated that EtOHVT, EtOHEC, and EtOHAM possess good antioxidant, antiinflammatory, analgesic, and antipyretic effects. These effects might be attributed to the presence of biologically active compounds. However, among the three plants studied, ETOHAM could be recommended in the effective treatment of inflammation in traditional medicine.

\section{Acknowledgments}

We are grateful to VNS Group of Institutions (Faculty of Pharmacy, Bhopal, India) and Institute of Medical Research and Medicinal Plants Studies (Yaoundé, Cameroon), for providing facilities and technical assistance.

Author contributions: RSP and RANN designed the study and supervised the work. ALMK, TKK, PP, and PNP did the laboratory experiments. ATT prepared the plant extracts. GAA and RSM wrote and reviewed the manuscript. All authors read and approved the submission of the final manuscript.

Research funding: This work was supported by the Centre for International Co-operation in Sciences (CICS) promoted by the Indian Science Academy (INSA) in association with the Scientific Agencies and Department through the INSA JRD-TATA Fellowship Programme.

Competing interests: Authors have declared that no conflict of interests exists.

Ethical approval: Research involving animals complied with all relevant national regulations and institutional policies (Committee for the Purpose of Control and Supervision of Experiments on Animals (CPCSEA), India) for the care and use of animals. (778/PO/a/03/CPCSEA: 03.09).

\section{References}

[1] Chen L, Deng H, Cui H, Fang ], Zuo Z, Deng ], Inflammatory responses and inflammation-associated diseases in organs. Oncotarget. 2017;9:7204-7218.

[2] Schetter A], Heegaard NH, Harris CC. Inflammation and cancer: interweaving microRNA, free radical, cytokine and p53 pathways. Carcinogenesis 2010;31:37-49.

[3] Highleyman L. HIV and inflammation. CMHC Treat Issues 2011;1-4.

[4] Becker K, Schroecksnadel S, Costner ], Zaknun C, Schennach H, Uberall F, et al. Comparison of in vitro tests for antioxidant and immunomodulatory capacities of compounds. Phytomedicine 2013;21:164-71.

[5] Azizi G, Navabi SS, Al-shukaili A, Seyedzadeh MH, Yazdani R, Mirshafiey A. The role of inflammatory mediators in the pathogenesis of Alzheimer's disease. Sultan Qaboos Univ Med ] 2015;15:305-16.

[6] Ashley NT, Weil ZM, Nelson R]. Inflammation: mechanisms, costs and natural variation. Annu Rev Ecol Evol Syst 2012;43:385-406.

[7] El-gamal MI, Bayomi SM, El-ashry SM, Said SA, Abdel-aziz AA, Abdel-aziz NI. Synthesis and anti-inflammatory activity of novel (substituted) benzylidene acetone oxime ether derivatives: molecular modeling study. Eur ] Med Chem 2010;45:1403-14.

[8] Margarethe MB, Bosmaden ML, Van Wetten ML, Pruimboom L. Chronic inflammatory diseases are stimulated by current lifestyle: how diet, stress levels and medication prevent our body from recovering. Nutr Metab 2012;9:32-46.

[9] Yu T, Lee ], Lee YG, Byeon SE, Kim MH, Sohn EH, et al. In vitro and in vivo anti-inflammatory effects of ethanol extract from Acer tegmentosum. ] Ethnopharmacol 2010;128:139-47.

[10] Eduardo CF, Ana IS, Balbin V, Cely MM, Miriam HT, Frederico OP, et al. Influence of steroidal anti-inflammatory drugs on viability and fertility of equine semen. J Equine Vet Sci 2012;32:771-5.

[11] Rang HP, Dale MM, Ritter JM, Flower R], Henderson G. Pharmacology, 7th ed. Philadelphia: Elsevier Churchill Livingstone, $2012: 777$.

[12] Bordonia A, Danesia F, Dardevet D, Dupont D, Fernandeze AS, Gille D, et al. Dairy products and inflammation: a review of the clinical evidence. Crit Rev Food Sci Nutr 2017;57:497-525.

[13] Adjanohoun JE, Aboubakar N, Dramane K, Ebot ME, Ekpere JA, Enoworock EG, et al. Traditional medicinal pharmacopoeia: contribution to ethnobotanical and floristics studies in Cameroon, 1st ed. Porto-Novo: CNPMS (Centre national de production de manuels scolaires), 1996:641.

[14] Kopa KT, Nyemb N, Tchamgoue DA, Nkoulou TT. Antihyperglycemic and anti-oxidant potential of ethanol extract of vitex thyrsiflora leaves on diabetic rats. Univ ] Pharm Res 2018;3:19-25.

[15] Noumedem AC, Pone W], Nguemfo TA, Mohanakrishnan D, Garima M, Dinkar S, et al. In vitro antiplasmodial and antioxidant activities of Entandrophragma cylindricum (Meliaceae) extracts. Eur ] Med Plants 2017;21:1-9.

[16] Ngnokam D, Massiot C, Bliard C, Tsamo E, Sapelenin D, a new acyclic triterpenoid from the stem bark of Entandrophragma cylindricum. Nat Prod Lett 1995;5:289-93. 
[17] Ngnokam D, Nuzillard JM, Bliard C. Sapelenin E and F: new acyclic triterpenoids from the stem bark of Entandrophragma cylindricum. Bull Chem Soc Ethiop 2005;19:227-31.

[18] Murata T, Miyase T, Muregi FW, Naoshima-Ishibashi Y, Umehara K, Warashina T, et al. Antiplasmodial triterpenoids from Ekebergia capensis. ] Nat Prod 2008;71:167-74.

[19] Tanaka Y, Yamada T, In Y, Muraoka O, Kajimoto T, Tanaka R. Absolute stereostructure of andirolides A-C from the flower of Carapa guianensis (Meliaceae). Tetrahedron 2011;67:782-92.

[20] Kouam SF, Kusari S, Lamshöft M, Tatuedom OK, Spiteller M. Sapelenins C-], acyclic triterpenoids with strong anti-inflammatory activities from the bark of the Cameroonian medicinal plant Entandrophragma cylindricum. Phytochemistry 2012;83:79-86.

[21] Mbula JP, Kwembe JT, Tshilanda DD, Ngobua KN, Kabena ON, Nsimba SM, et al. Antisickling, antihemolytic and radical scavenging activities of essential oil from Entandrophragma Cylindricum (Sprague) Sprague (Meliaceae). J Adv Med Life Sci 2018;6:1-5.

[22] Noumi E, Eloumou ME. Syphilis ailment: prevalence and herbal remedies in Ebolowa subdivision. South region, Cameroon. Int] Biomed Pharmaceut Sci 2011;2:20-8.

[23] Kuete V, Fankam CA, Wiench B, Efferth T. Cytotoxicity and modes of action of the methanol extracts of six Cameroonian medicinal plants against multidrug-resistant tumor cells. Evid Based Complement Alternat Med ID 285903, 2013.

[24] Achenbach H, Renner C. Constituents of West African medicinal plants. XVIII: the annonidines - a new class of prenylated bisindole alkaloids from Annonidium mannii. Heterocycles 1985;23:2075-81.

[25] Khandelwal KR. Practical pharmacognosy: techniques and experiments, 9th ed. Pune: Nirali prakashan, 2002:320.

[26] OECD. Guidelines for testing of chemicals. Revised Draft Guidelines 425: Acute Oral Toxicity - Up and Down Method. Paris: Organization for Economic Co-operation and Development, 2001:29.

[27] Vinson JA, Dabbagh YA, Serry MM, Jang J. Plant flavonoids, especially tea flavonols, are powerful antioxidants using an in vitro oxidation model for heart disease. ] Agric Food Chem 2001;43:2800-3.

[28] Liu X, Zhao M, Wanga ], Yang B, Jiang Y. Antioxidant activity of methanolic extract of emblica fruit (Phyllanthus emblica L.) from six regions in China. J Food Compost Anal 2008;21:219-28.

[29] Benzie IF, Strain ]J. The ferric reducing ability of plasma (FRAP) as a measure of antioxidant power: the FRAP assay. Anal Biochem 1996;239:70-6.

[30] Mensor LL, Menezes FS, Leitao CG, Reis AS, Dos Santos TC, Coube CS, et al. Screening of Brazilian plant extracts for antioxidant activity by the use of DPPH free radical method. Phytother Res 2001;15:127-30.

[31] Rutch R], Cheng S], Klaunig JE. Prevention of cytotoxicity and inhibition of intercellular communication by antioxidant catechins isolated from Chinese green tea. Carcinogenesis 1989;10:1003-8.

[32] Re R, Pellegrini N, Proteggente A, Pannala A, Yang M, Rice-Evans C. Antioxidant activity applying an improved ABTS radical cation decolorization assay. Free Radic Biol Med 1999;26:1231-7.

[33] Padmanabhan P. Evaluation of in-vitro anti-inflammatory activity of herbal preparation, a combination of four herbal plants. Int ] Appl Basic Med Res 2012;2:109-16.

[34] Majumder MM, Mazumder EH, Alam MA, Akter R, Rahman M, Sarker SD. Antioxidant and membrane stabilizing properties of Ichnocarpus frutescens. J Nat Remedies 2008;8:209-15.

[35] Mahat MA, Patil BM. Evaluation of anti-inflammatory activity of methanol extract of Phyllanthus amarus in experimental animal models. Indian J Pharm Sci 2007;69:33-6.

[36] Veerappan A, Miyazaki S, Dhananjavan R. Studies on the anti-inflammatory, antipyretic and analgesic properties of the leaves of Aegle marmelos Corr. ] Ethnopharmacol 2005;96:159-63.

[37] Owoyele BV, Oguntoye SO, Darel K, Alice B. Analgesic, anti-inflammatory and antipyretic activities from flavonoid fractions of Chromolaena odorata. J Med Plants Res 2008;2:219-25.

[38] Attiq A, Jalil ], Husain K. Annonaceae: breaking the wall of inflammation. Front Pharmacol 2017;8:752-76.

[39] Ngnokam D, Mawot G, Nuzillard JM, Tsamo E. (+)-7,7'-Dimethyl-5-hydroxy-2R,3S-trans-pubeschin from Entandrophragma cylindricum. Phytochemistry 1994;37:529-31.

[40] Kopa KP, Tane P, Wabo KH, Tala FM, Tchinda TA, Zofou D, et al. In vitro antiplasmodial activity of the isolated compounds from the stem bark of Vitex thyrsiflora. C R Chim 2016;19:807-11.

[41] Piluzza C, Bullitta S. Correlations between phenolic content and antioxidant properties in twenty-four plant species of traditional ethnoveterinary use in the Mediterranean area. Pharm Biol 2011;49:240-7.

[42] Terpinc P, Čeh B, Ulrih NP, Abramovič H. Studies of the correlation between antioxidant properties and the total phenolic content of different oil cake extracts. Ind Crop Prod 2012;39:210-7.

[43] Aryal S, Baniya MK, Danekhu K, Kunwar P, Gurung R, Koirala N. Total phenolic content, flavonoid content and antioxidant potential of wild vegetables from Western Nepal. Plants 2019;8:1-12.

[44] Serna DM, Martínez ]H. Phenolics and polyphenolics from Melastomataceae species. Molecules 2015;20:17818-47.

[45] Srinivasan R, Natarajan D, Shivakumar MS. Antioxidant compound quercetin-3-O- $\alpha$-L-rhaminoside $(1 \rightarrow 6)-\beta$-D-glucose (rutin) isolated from ethyl acetate leaf extracts of Memecylon edule Roxb (Melastamataceae). Free Rad Antiox 2015;5:35-48.

[46] Awah FM, Uzoegwu PN, Ifeonu P, Oyugi JO, Rutherford ], Yao X], et al. Free radical scavenging activity, phenolic contents and cytotoxicity of selected Nigerian medicinal plants. Food Chem 2012;131:1279-86.

[47] Higdon JV, Frei B. Tea catechins and polyphenols: health effects, metabolism, and antioxidant functions. Crit Rev Food Sci Nutr 2003;43:89-143.

[48] Crant NH, Album HE, Kryzanauskas C. Stabilization of serum albumin by anti-inflammatory drugs. Biochem Pharmacol 1970;19:715-22.

[49] Alberts. Biologie moléculaire de la cellule, 5th ed. Paris: Medecine Science, Lavoisier, 2011:1601.

[50] Shah SM. A possible anti-inflammatory mechanism of ethyl acetate extracts of Teucrium stocksianum Bioss. BMC Complement Altern Med 2015;15:299-308.

[51] Mukundi M], Mwaniki NE, Piero NM, Murugi N], Daniel AS. In vivo anti-diabetic effects of aqueous leaf extracts of Rhoicissus tridentata in Alloxan induced diabetic Mice. J Develop Drugs 2015;4:131-6. 
[52] Pan MH, Lai CS, Ho CT. Anti-inflammatory activity of natural dietary flavonoids. Food Funct 2010;1:15-31.

[53] Mencarelli A, Renga B, Palladino G, Distrutti G, Fiorucci S. The plant sterol guggulsterone attenuates inflammation and immune dysfunction in murine models of inflammatory bowel disease. Biochem Pharmacol 2009;78:1214-23.

[54] Nakanishi T, Mukai K, Yumoto H, Hirao K, Hosokawa Y, Matsuo T. Anti-inflammatory effect of catechin on cultured human dental pulp cells affected by bacteria-derived factors. Eur ] Oral Sci 2010;118:145-50.

[55] Cheng AW, Tan X, Sun JY, Gu C-M, Liu C, Guo X. Catechin attenuates TNF- $\alpha$ induced inflammatory response via AMPK-SIRT1 pathway in 3T3-L1 adipocytes. PLoS One 2019;14:e0217090.

[56] Hussein SS, Kamarudin MN, Kadir HA. (+)-Catechin attenuates NF- $\kappa B$ activation through regulation of Akt, MAPK, and AMPK signaling pathways in LPS-induced BV-2 microglial cells. Am J Chin Med 2015;43:927-52.

[57] Fan FY, Sang LX, Jiang M. Catechins and their therapeutic benefits to inflammatory bowel disease. Molecules 2017;22:484.

[58] Mangels DR, Mohler ER. Catechins as potential mediators of cardiovascular health. Arterioscler Thromb Vasc Biol 2017;37:757-63.

[59] Dos santos DA, Fukui MD, Dhammika NN, Khan SI, Sousa JP, Bastos ]K, et al. Anti-inflammatory and antinociceptive effects of Baccharis dracunculifolia DC (Asteraceae) in different experimental models. J Ethnopharmacol 2009;127:543-50.

[60] Aronoff DM, Neilson EC. Antipyretics: mechanisms of action and clinical use in fever suppression. Am ] Med 2001;111:304-15.

[61] Westfall TC, Westfall DP. The pharmacological basis of therapeutics: adrenergic agonists and antagonists, 12th ed. New York: McCrawHill Companies, 2011:2109.

Supplementary Material: The online version of this article offers supplementary material (DOI: https:/ /doi.org/10.1515/jbcpp-2019-0053). 